\title{
NEW ASPECTS ON ENHANCING BIOLOGICAL PROCESSES IN SANITARY LANDFILL
}

\author{
R. Stegmann*
}

(Received 18 May 1983)

\begin{abstract}
A short literature review shows that a lot of information is available concerning the biological processes that take place in sanitary landfill sites. Although there are still many unknown interactions and phenomena this information could be used to modify the conventional landfill operation technique so that methane production is enhanced. Results from research projects are presented, showing effects of landfill operation on the leachate quality with time. Laboratory scale experiments in which shredded municipal solid waste is anaerobically decomposed under optimum conditions give additional information concerning the reasons for enhancement or inhibition of the biological processes. Proposals for modified landfill operation techniques are presented.
\end{abstract}

Key Words-Municipal solid waste, sanitary landfill, leachate quality, gas production, enhancement, anaerobic fermentation, landfill operation, leachate recirculation

\section{Introduction}

There has been little change in waste disposal techniques since sanitary landfills were initiated. Municipal solid waste (MSW) is usually disposed of in $2 \mathrm{~m}$ lifts and is more or less highly compacted. Dependent upon the country and the specific situation the refuse may or may not be covered daily.

It has been known for some time that biological processes take place in landfill sites and that they are responsible for the degradation of organic fractions in the waste. Most landfill operators would like to minimize the time period of degradation in order to have less gas emissions after the landfill is closed and to be more successful in reclaiming the landfill.

There is another reason why enhancement of biological processes is desirable; since many of the new constructed landfills are sealed at the bottom (in Germany this is common practice); the leachate becomes a problem. High organic concentrations require a high oxygen supply during aerobic treatment which results in high energy costs (Stegmann \& Ehrig 1980). When enhancement of biological processes is achieved in the landfill the period of time when leachate is highly polluted by organics decreases. The efforts to treat the leachate will be reduced.

As another consequence gas production will be concentrated over a shorter period of time; utilization of the gas may start during the operation phase of the landfill which has consequences on the kind of gas extraction system that should be installed (i.e. horizontal systems) as well as the kind of gas utilization. Mobile equipment (i.e. mobile gas engines with generator) may be in some cases the answer.

Although, these benefits are more or less known, little has been done to change the landfill operation technique in order to provide better environmental conditions for the relevant types of microorganism. It is well known from sludge digestors, that the sludge

*'Technische Universität Hamburg-Harburg, Eißendorfestr. 38, 2100 Hamburg 90, FRD. 
loading, temperature, mixing of the sludge etc. have to be controlled in order to get rapid and stable digestion processes. Landfill operation is much more rough and uncontrollable than a sludge digestion facility; but the influence of loading rates (or time sequences of building up the refuse lifts) should be taken into consideration, when new landfill methods are tested.

There are research activities in the field of enhancing the anaerobic processes in landfill sites in operation: three projects are running in the U.S.A. (Pacey 1982; Walsh 1983; Wehran 1983), there is one project in Switzerland (Gandolla 1982) and three projects in West Germany (Cord-Landwehr 1979; Ehrig 1982; Stegmann 1982); laboratory scale tests are run also in Austria (Scharf 1982). There is one big project in Germany in preparation. In the past research activities have been practised mainly in the U.S. (i.e. Merz 1963; Emcon Ass. 1974; Ham 1982; Pohland 1975). All these projects have as their aim to get further information about the interdependencies of environmental conditions and methane production. Variables as sludge addition, moisture content, leachate recirculation, temperature-control, aerobic pretreatment, addition of an inoculum and shredding have been installed in test fields and/or lysimeters. Problems always occurred when shredded MSW was placed in gas tight containers or columns. In these cases methane production was in general very poor (Emcon Ass. 1980).

\subsection{Conclusion from these research activities}

As a brief summary of these research activities, the following tendencies show up:

- Recirculation of leachate enhances methane production (Pohland 1975; CordLandwehr 1979; Ehrig 1980).

- Shredding has no real benefits in regard to enhancement (Ham 1982).

- Daily cover has an adverse effect on enhancement (Ham 1982).

- Refuse built up in 2-m lifts has also an adverse effect on enhancement in comparison with 1.3-m lifts (Ham 1982).

- Addition of sludge enhances gas production when digested sludge is added to MSW in a high proportion (Ehrig 1982; Gandolla 1982; Scharf 1982; Stegmann 1982).

- Gas production is very much dependent upon temperature; higher gas production rates were measured in the thermophilic phase (Scharf 1982).

- MSW compacted in thin layers without cover soil produce high strength leachate over shorter periods of time (Ehrig 1980).

- Landfilling of refuse with low density results in shorter periods of high strength leachate production (Ehrig 1980).

These are some of the possible conclusions drawn from results described in the literature as well as from own experiments. In the following chapters further information will be given and as a crnsequence possible modified landfill operation techniques will be discussed. The detailed description of the biochemical processes that take place in landfill can be found elsewhere (Stegmann \& Ehrig 1980, 1982; Emcon Ass. 1980).

\section{Results from different activities}

\section{Sanitary landfill and lysimeter studies}

It has been observed that the $\mathrm{BOD}_{5}$-concentrations in leachate-once they have decreased to low values - stay at low concentrations although MSW is still landfilled on top. This means that in the bottom part of the landfill anaerobic microorganism 


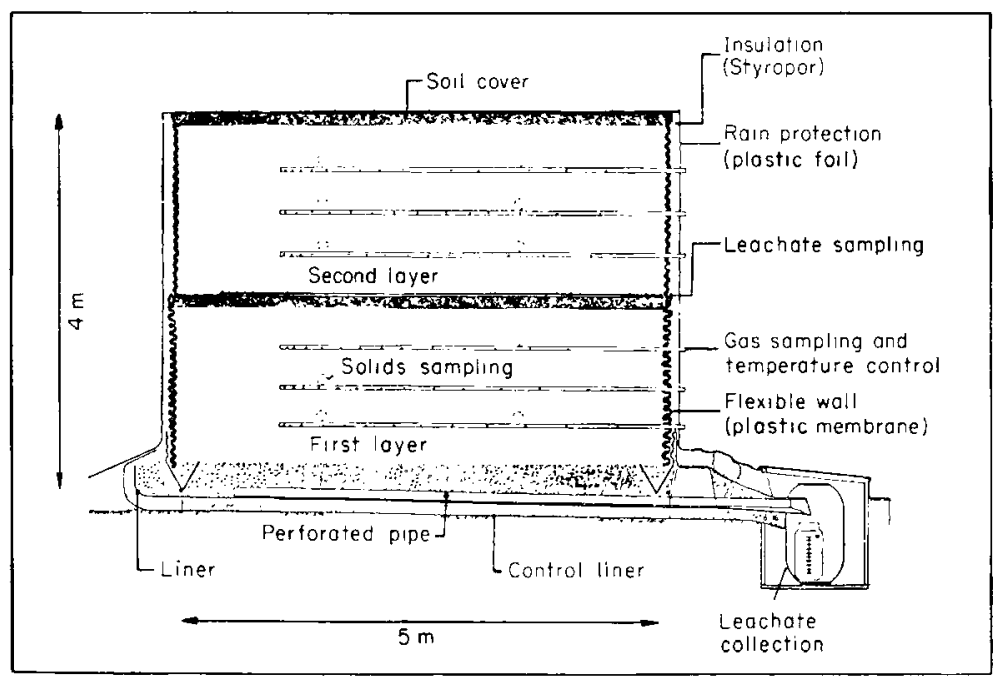

Fig. 1. Cross section of the lysimeter.

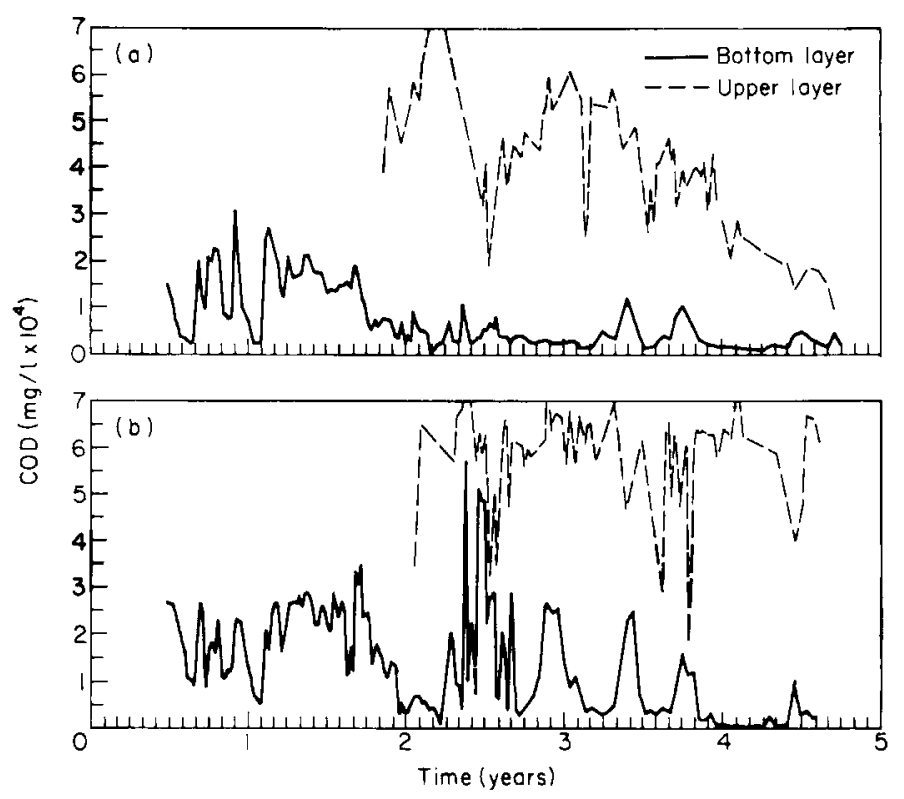

Fig. 2. COD-concentrations of leachate samples collected at the bottom and between the first and second layers of two different outdoor lysimeters. (a) Lysimeter No. 3: high compacted MSW in $40 \mathrm{~cm}$ lifts; each lift has been built up in 6 weeks. Lysimeter No. 4: MSW and aerobic stabilized sewage sludge mixture was highly compacted in two $2 \mathrm{~m}$ lifts (Stegmann \& Ehrig 1982).

have developed, that convert the organics present in the leachate mostly to $\mathrm{CO}_{2}$ and methane.

The above described observations have been varified by setting up lysimeters in two different lifts (Stegmann \& Ehrig 1982). The lysimeters were filled with MSW and have been compacted up to a density of around $0.8 \mathrm{t} / \mathrm{m}^{3}$ (Fig. 1). After the $\mathrm{BOD}_{5}$-concentrations had decreased to very low values the second $2 \mathrm{~m}$ lift was put on top of the first lift. In this experiment it was possible to sample leachate from the area between the 
first and second lift. Very high organic concentrations have been measured in the leachate samples from between the lifts but there was no significant increase in $\mathrm{BOD}_{5}$ and COD-concentrations in the leachate at the bottom (Fig. 2). Leachate has been treated anaerobically in the first lift.

\subsection{Column tests}

In a column test, high concentrated leachate has been pumped on top of anaerobicallyfermented MSW; after the leachate has migrated through the $1.50 \mathrm{~m}$ high MSW-column $\mathrm{BOD}_{5}$-concentrations $<100 \mathrm{ppm}$ were measured. Gas was produced in significant amounts (0.9-1.3 $\mathrm{m}^{3} / \mathrm{kg} \mathrm{BOD}_{5}$-reduction) (Fig. 3). From these tests it can be concluded that at temperatures around $30^{\circ} \mathrm{C}$ about $1 \mathrm{~kg} \mathrm{BOD}_{5}$ can be treated by percolating through $1 \mathrm{t}$ of anaerobically-decomposed MSW. Evaluating the results from the above described lysimeter tests only $0.01 \mathrm{~kg} \mathrm{BOD}_{5} / \mathrm{t}$ dry MSW had been treated (temperatures $\sim 10-15 \mathrm{C}$ ).

\subsection{Laboratory scale iests}

Test facilities have been developed to study the anaerobic processes in MSW (Fig. 4). Initially they were designed to simulate codisposal of MSW and industrial refuse (Stegmann 1981).
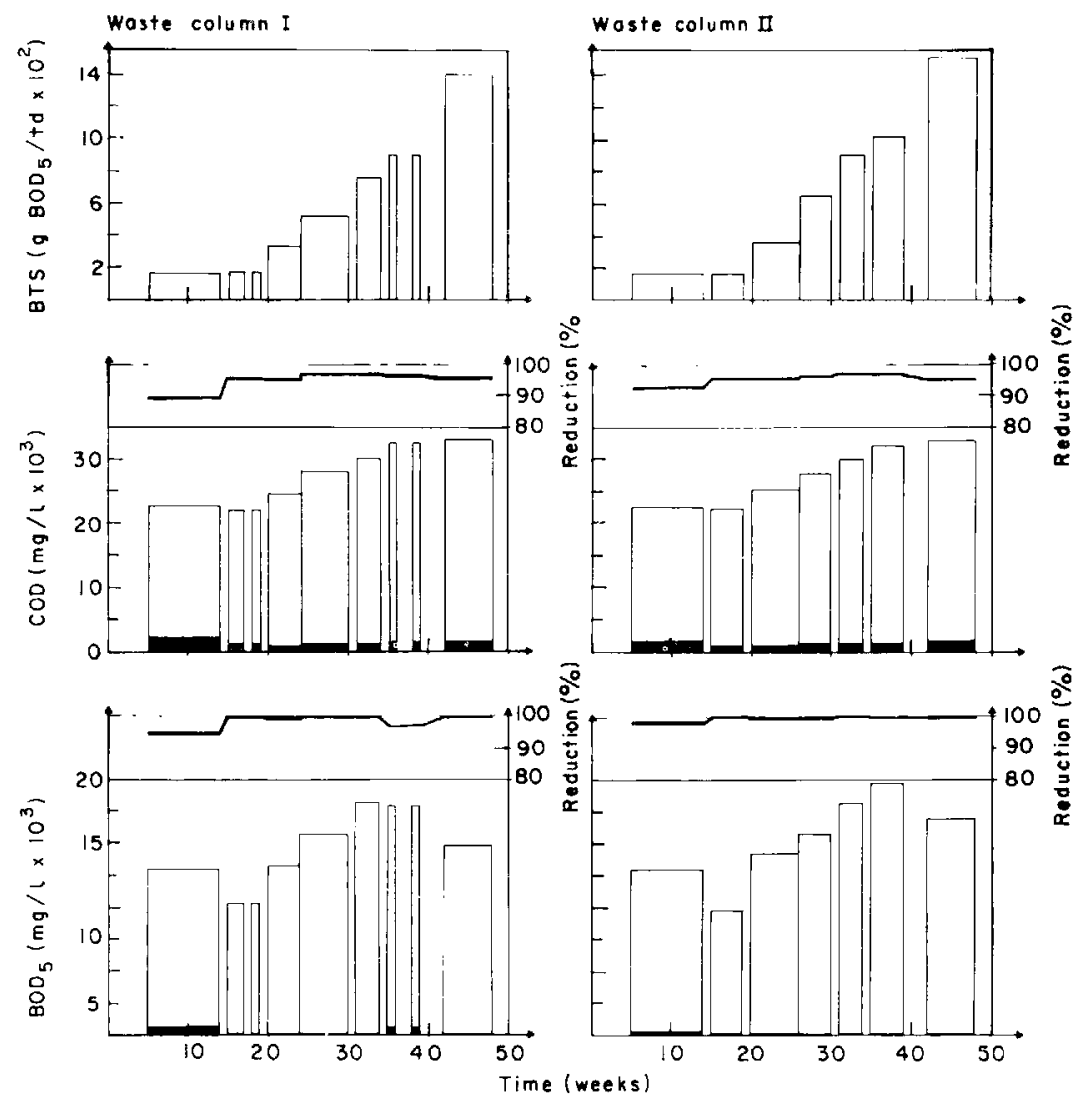

Fig. 3. Degradation of leachate in anaerobically fermented MSW columns (laboratory scale, 30 C). [BTS: organic load ( $\mathrm{g} \mathrm{BOD}_{5} / \mathrm{t}$ dry MSW/day)]. $\square$, initial leachate concentrations: after percolation through column I resp. column II 


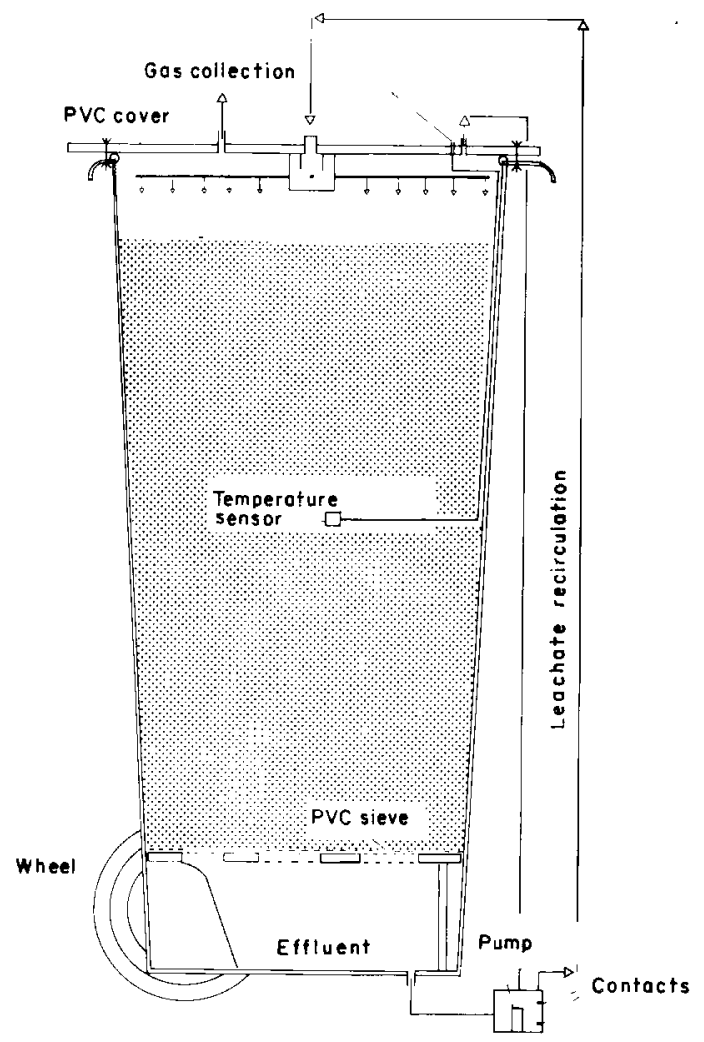

Fig. 4. Cross section of the laboratory scale test cell (Stegmann 1981).

The first gas tight containers were filled with shredded MSW brought to $65 \%$ moisture content (room temperature $30^{\circ} \mathrm{C}$ ). There was no leachate recirculation. The produced gas was collected in gas-tight gas bags connected with tubings to the containers. There was quite a $\mathrm{CO}_{2}$-production but the methane phase has not started even after 1 year. The author believes that the high organic acid concentrations result in a preservation of the refuse since the environmental conditions are not appropriate for methane producing bacteria (organic acid-alkalinity ratio should be $\leqslant 0.8$ ) (Kugelmann \& Chin 1971).

The situation may be improved, when water percolates through refuse, and part of the organic acids are removed by the leachate; if high organic acid concentrations are present, it may happen that an uninhibited methane production will not develop since together with the organic acids also buffer $\left(\mathrm{HCO}_{3}\right)$ will be removed and by the time the organic acids are reduced to acceptable concentrations the buffer capacity may be too low.

To improve the conditions for the methane-producing bacteria, sludge and composted refuse were added to the shredded MSW. The sludge was anaerobically fermented but not dewatered (solid content $\sim 9 \%$ ) so that the portion of sludge solids to MSW-solids was only $\sim 14 \%$. In one test, only composted refuse was used (composted over a period of 1-2 months). Figure 5 shows the results, indicating the positive effect of adding composted MSW to the MSW or even only using composted MSW. In this figure the $\mathrm{BOD}_{5}$-concentrations indicate the rapid decrease of organic concentrations in the 

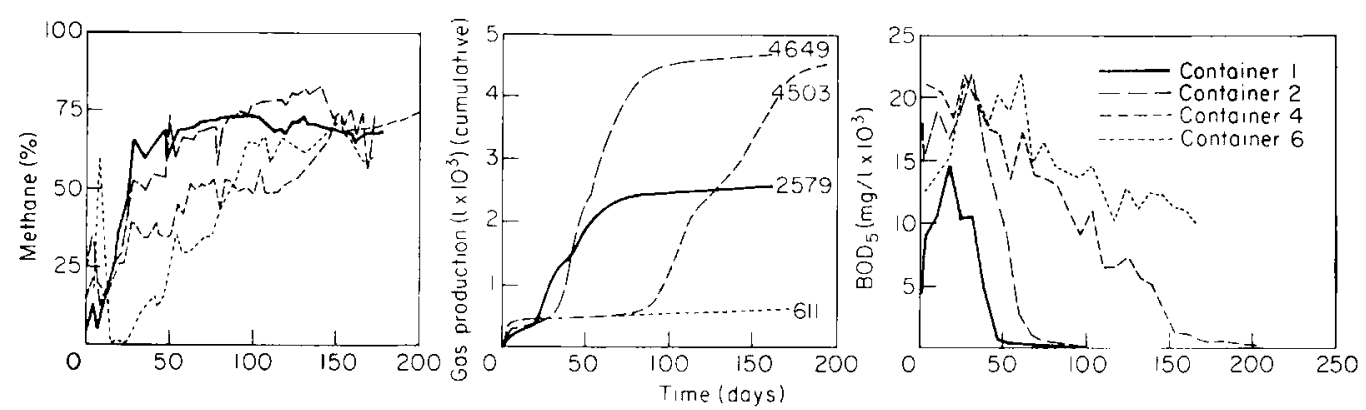

Fig. 5. Results from test series CDO using test container described in Fig. 4 (Stegmann 1982). Container 1: Compacted MSW (time period 6-8 weeks). Container 2: MSW and compacted MSW in relation 1:1 (dry weight basis). Container 4: MSW and sewage sludge 7:1 (dry weight basis). Container 6: MSW and sewage sludge 7:1 (dry weight basis) with $\mathrm{pH}$ adjustment to $\mathrm{pH} \sim 7$ (Addition of $\mathrm{NaOH}$ ). All tests at moisture content of $65 \%$ and $30 \mathrm{C}$ room temperature.

leachate, after the methane production has started. Note that the addition of $\mathrm{NaOH}$ had no effect on the enhancement of methane production. Increasing the $\mathrm{pH}$ does not change the organic acid-alkalinity ratio; after the methane phase is reached the $\mathrm{pH}$ rises automatically. Information from test series that are still in operation should also be mentioned:

- The addition of inorganic material like metal sludges, demolition material etc. to shredded MSW enhanced gas production.

- The addition of food waste like vegetables, fruits etc. resulted in an inhibition of the methane production until now. These tests are still running but as a tendency it becomes obvious that the methane production is somewhat inhibited compared to the test container filled with MSW and composted MSW (both shredded).

- The addition of sawdust (pine tree) to MSW enhanced gas production; the same effect was observed, when newspaper and cardboard were added.

These observations support the theory that inhibition of methane production will be caused by high concentrations of organic acids. Inert material added to MSW tend to "dilute" the organic acids, so that in the average the organic acid concentrations related to the solids are lower.

For our co-disposal tests, all the biological phases that take place in an acutal landfill had to be subjected to all kinds of industrial wastes; the tests should be terminated after 6-12 months. For this reason $\sim 30 \%$ of composted MSW (1-2 months old) was added to the shredded MSW. As an example the results from one test are presented in Figs 6 and 7.

The typical gas composition pattern was first presented by Farquhar \& Rovers (1973). The measured gas compositions in the test container are very similar to the theoretically determined curves mentioned above. Note the plateau at $50 \%$ methane; this kind of plateau was observed by almost all our tests; it is likely that mostly acetic acid is converted to $\mathrm{CO}_{2}$ and methane, since the anaerobic fermentation of acetic acid results in the above mentioned gas composition. Often a second (much smaller) peak at $65-70 \%$ methane could be detected. More research activities have to be done to identify in more detail the succession of the degradation of the organic components in the MSW. Since methane concentrations become higher as the degradation processes proceed, this might be an indicator to interpret gas concentrations measured in actual landfill.

In order to get samples from leachate in the test container, 1.51 of leachate had to 


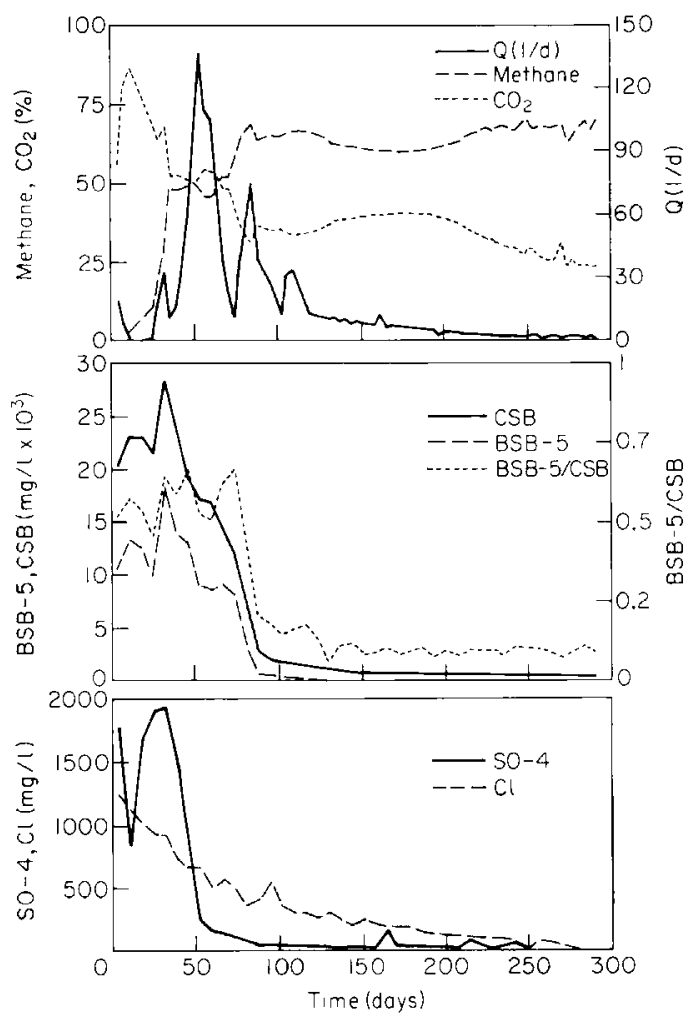

Fig. 6. Results from container test CD2-3; MSW: composted MSW = 2:1 (dry weight basis) 65\% moisture content, $30^{\circ} \mathrm{C}$ room temperature (Stegmann 1982).

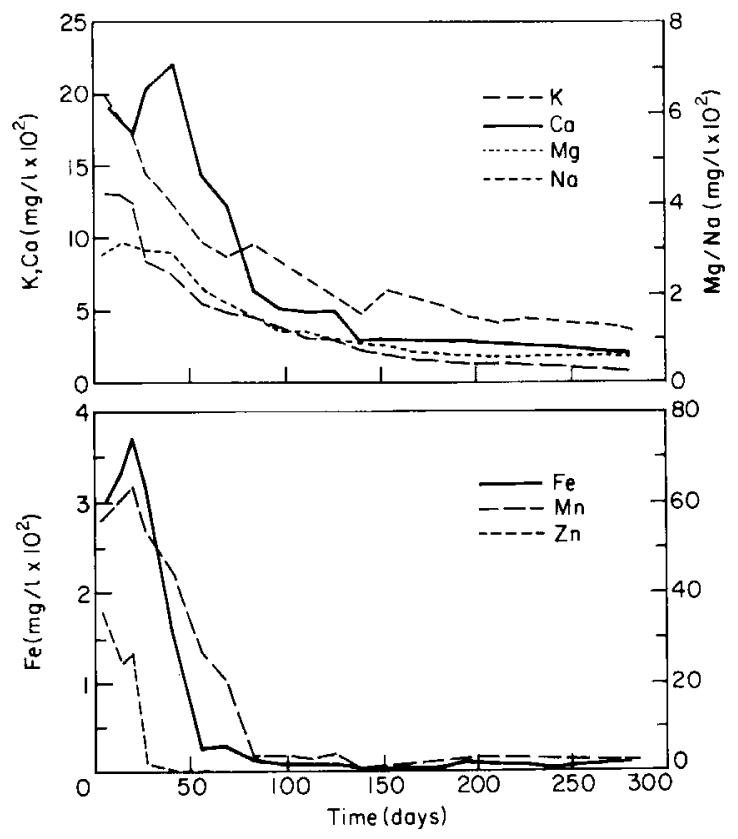

Fig. 7. Results from container test CD2-3 (Fig. 6 continued) (Stegmann 1982). 
be removed; the same amount of tap water was put back into the container in order to keep the moisture content constant. As a consequence a leaching effect could be observed where the chloride concentrations may be taken as an indicator. Comparing other components with the chloride concentrations with time, it becomes obvious, that the organic concentrations behave completely different. The $\mathrm{BOD}_{5}$ and $\mathrm{COD}$ concentrations decrease dramatically when stable methane production takes place. Note that organic leachate concentrations may be still high, although gas production is at a peak. For this reason organic leachate concentration cannot always be used as an indicator for the gas production and gas composition. This goes well together with observations in the field, where high gas production rates with methane-concentrations around $50 \%$ have been measured in refuse 1 year after piacement (high compaction, $\mathrm{BOD}_{5}$ concentrations in the leachate $\sim 20,000 \mathrm{ppm}$ ).

\section{Suggestions}

As already mentioned results from laboratory and half scale technical experiments do not correspond necessarily with what can be expected in the field, but tendencies and general know-how can be transfered to landfill conditions. The following operation techniques should be tested in full scale; the author is well aware of disadvantages that are connected with some of these new techniques.

- The first layer of a landfill can be prepared in such a way, that the polluted leachate from the lifts above can be treated in this area. The first layer of refuse (1.5-2 $\mathrm{m}$ height) has to be placed in an uncompacted way, so that ready degradable organics can decompose aerobically; leachate recirculation should be practised. The rate of recirculation should be optimized in order to avoid anaerobic conditions. After 1 year of placement the usual landfill operation can be started. The disadvantage of this procedure is a high leachate production rate during the first year.

The procedure is tested in a research project which was initiated by the author at the sanitary landfill of Lingen. Two sections of the landfill (each 1 ha size) were filled with MSW. In one section the refuse was highly compacted in $0.5-1 \mathrm{~m}$ lifts. In the other section the refuse was placed $1 \mathrm{~m}$ high without any compaction. After 6 months another lift of one meter was placed on top of the first lift in the same manner. Refuse was disposed of in high compacted $2 \mathrm{~m}$ lifts, after another 6 months. Leachate recirculation has been practised in both fields. Figure 8 shows the leachate quality data from both sections indicating the advantage of the uncompacted layers. The last numbers from December 1982 show COD concentrations around $2000 \mathrm{ppm}$ in the landfill section with the uncompacted bottom layer, while in the parallel section ten times higher COD-concentrations were measured. As already mentioned, high leachate production rates have been detected during the year where the uncompacted refuse stayed in the landfill. Efforts should be made in order to reduce the time for the aerobic decomposition of the first layer, i.e. by supporting air flow through perforated pipes, or other systems.

- Leachate recirculation should be practised in any way during landfill operation. In order to avoid odour problems during spray irrigation, a leachate pretreatment step should be practised in the first years when high polluted leachate is expected (Stegmann \& Ehrig 1980). Spray irrigation is advantageous since it equalizes distribution and spray losses enhance evapotranspiration. 

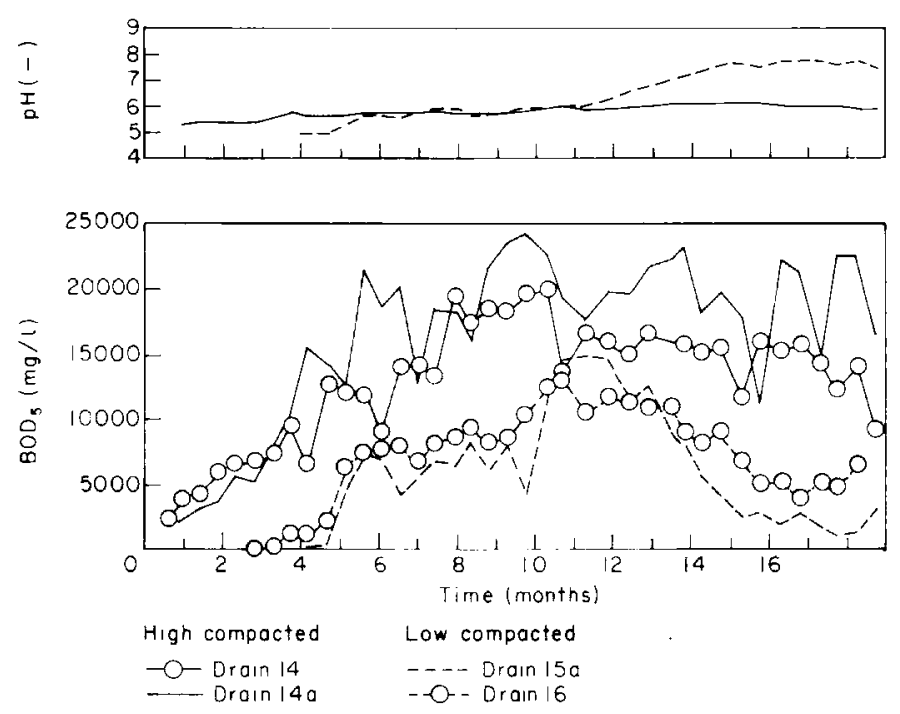

Fig. 8. $\mathrm{BOD}_{5}$-leachate concentrations from two test fields (full scale operation) at the sanitary landfill of Lingen, West Germany. Drain 14, 14a: high compacted refuse in $0.5-1 \mathrm{~m}$ lifts; leachate recirculation. Drain 15a. 16: uncompacted layer of refuse is covered with refuse ( $2 \mathrm{~m}$ lifts, high compaction) after 1 year of placement; leachate recirculation.

- If possible the refuse should be compacted in thin layers $(20-30 \mathrm{~cm}$ lifts) over large areas. This technique results in higher leachate production rates (compared to techniques where the refuse is built up to the final height in small sections in a short period of time) but leachate concentrations are expected to decrease earlier. Since large areas of refuse are in contact with the atmosphere aerobic processes take place to a certain degree reducing the readily degradable organic fractions. Moisture distribution by the recirculated leachate and precipitation is much more even.

- During landfill operation the refuse should be covered with soil only when the section is finished; daily covering should be avoided, although many authorities require daily cover.

- Since own experiments indicate that the addition of an inert material to MSW in an amount of about $25 \%$ by weight enhanced methane production, a first layer could be built up with high portions of, i.e. demolition waste; when the $\mathrm{BOD}_{5}$-concentrations are reduced to $<1000 \mathrm{ppm}$ a new lift of refuse could be placed on top, where the thin layer technique should be practised.

The aerobic landfill (Rottedeponie) has advantages concerning lower leachate concentrations $\left(\mathrm{COD}, \mathrm{BOD}_{5}\right.$ ) with time but it has a lot of disadvantages, too. Since compaction is low during the whole life of the landfill, high leachate production rates can be anticipated (Ehrig 1980). Low compaction rates mean that less refuse can be disposed of in the same volume and the possibility of the development of bugs cannot be ignored.

All these ideas have only partly or not been proven in practise for a longer period of time. These ideas should help landfill operators to test new or modified landfill techniques that may improve environmental conditions in and around a landfill. There is no great risk since these techniques are not expected to be more costly than conventional methods. The author has applied together with other institutions for a research 
grant to test the above described influences in more detail and in addition to try other concepts in order to control anaerobic processes in landfill to a certain degree.

\section{Summary}

Sanitary landfill operation technique has not changed for a long time, although a lot of information is available concerning the biological processes during the anaerobic decomposition of MSW. One aim should be to enhance these processes in order to minimize leachate emissions and optimize gas production; in addition land reclamation will be much easier.

From the literature the positive effects of leachate recirculation, avoiding cover material, building up landfills in high compacted lifts $(<0.5 \mathrm{~m})$ over large areas on enhancement can be learned. There are a lot of indications that the MSW load/area and time may be an important parameter to control biological processes.

Since leachate treatment is very costly the leachate should be partially treated in the landfill itself. Many observations from experiments show that once the organic leachate concentrations have decreased, they stay low although refuse is still landfilled on top. Promising results have been achieved by placing a non-compacted partly aerobically decomposed layer of refuse at the bottom of the fill. High-strength leachate from fresh refuse will be partly treated under anaerobic conditions.

Anaerobic decomposition of shredded MSW is observed in laboratory-scale gas-tight containers, where leachate is recirculated. The addition of one-third of composted MSW enhanced methane production. Simultaneous gas and leachate quality data have been created, showing interdependencies between organic leachate concentrations and gas production as well as methane concentrations.

In the conclusions ideas of new landfill operation techniques are presented. Landfill operators are recommended to test modified techniques as leachate recirculation, low MSW loadings, lifts $<0.5 \mathrm{~m}$, special prepared lifts and the addition of inert materials. There are other techniques that could be thought of. When new techniques are tested, the conventional technique should be practiced in parallel; a monitoring programme on leachate and gas quality should also be set up.

\section{References}

Cord-Landwehr, K. (1979), Sickerwasserreinigung mit den SK-Verfahren. (Leachate treatment by means of recirculation). Müll und Abfall, Heft 11, Erich Schmidt Verlag.

Ehrig, H.-J. (1980), Beitrag zum quantitativen und qualitativen Wasserhaushalt von Mülldeponien. (Quantitative and qualitative water budget in sanitary landfills). Veröffentlichungen des Instituts für Stadtbauwesen, T.U. Braunschweig, Heft 26, Eigenverlag.

Ehrig, H.-J. (1982), Ergebnisse von Abbauuntersuchungen in Lysimetern. (Results from investigations on degradation processes in lysimeters). Gas and Wasserhaushalt-Veröffentlichungen des Instituts für Stadtbauwesen, T.U. Braunschweig, Heft 33, Eigenverlag.

Emcon, Ass. (1974), Sonoma County Refuse Stabilization Study Project, G 06-EC-0035 County of Sonoma, Department of Public Works.

Emcon, Ass. (1980), Enhancing production of landfill gas, prepared for Argonne National Laboratories, Pacific Gas and Electric Company and Southern California Gas Company. Emcon Associates, San José, California.

Farquhar, G. J. \& Rovers, F. A. (1978), Gas production during refuse decomposition. Water, Air and Soil Pollution, 2, 483.

Gandolla, M. (1982), Ergebnisse von Lysimetern auf der Deponie Croglio, Schweiz. (Results from lysimeter studies at the Sanitary landfills of Croglio, Switzerland). Gas and Wasserhaushalt von Mülldeponien-Veröffentlichungen des Instituts für Stadtbauwesen, T.U. Braunschweig, Heft 33, Eigenverlag. 
Ham, R. K. (1982), Ergebnisse des Abbaus von Müll in Testzellen in Madison. (Degradation of municipal solid waste in test cells in Madison, Wisc. U.S.A.). Gas und Wasserhaushalt von Mülldeponien-Veröffentlichungen des Instituts für Stadtbauwesen, T.U. Braunschweig, Heft 33, Eigenverlag.

Kugelmann, I. J. \& Chin, K. K. (1974), Toxicity, synergism and antagonism in anaerobic waste treatment processes. Advances in Chemistry, Series 105, American Chemical Society, Washington, D.C.

Merz, R. C. (1963), Determination of the quantity and quality of gas produced during refuse decomposition. University of Southern California, School of Engineering, USCEC Report $89-6$.

Pacey, J. (1982), Demonstrationsprojekt einer gelenkten Fermentation in Deponien. (Demonstration project of controlled fermentation processes in landfills). Veröffentlichungen des Instituts für Stadtbauwesen, T.U. Braunschweig, Heft 33, Eigenverlag.

Pohland, F. G. (1975), Sanitary landfill stabilization with leachate recycle and residual treatment. $E P A-600 / 2-75-043$.

Scharf, W. (1982). Untersuchungen zur gemeinsamen Ablagerung von Müll und Klärschlamm im Labormaßstab. (Codisposal of municipal solid waste and sewage sludge; investigations in laboratory scale). Gas und Wasserhaushalt von Mülldeponien-Veröffentlichungen des Instituts für Stadtbauwesen, T.U. Braunschweig, Heft 33, Eigenverlag.

Schlegel, H. G. (1972), Allgemeine Mikrobiologie. Georg Thieme Verlag Stuttgart.

Stegmann, R. (1982), Ergebnisse von Abbauversuchen im Labormaßstab. (Description of biological degradation processes of municipal solid waste in laboratory scale lysimeter). Gas und Wasserhaushalt von Mülldeponien - Veröffentlichungen des Instituts für Stadtbauwesen, T.U. Braunschweig, Heft 33, Eigenverlag.

Stegmann, R. (1981), Criteria for the codisposal of municipal and industrial wastes. EAS-ISWADocumentation, München 22.-26. Juni; Herausgeber EAS-Sekretariat, ATV 5205 St. Augustin, Postfach, West-Germany.

Stegmann, R. \& Ehrig, H.-J. (1980), Entstehung von Gas und Sickerwasser in geordneten Deponien. (Development of gas and leachate in sanitary landfills). Müll und Abfall, Heft 2, Erich Schmidt Verlag.

Stegmann, R. \& Ehrig, H.-J. (1980), Operation and design of biological leachate treatment plants. Progress Water Technology Vol. 12, Toronto, pp. 919-947. IAWPR/Pergamon Press.

Stegmann, R. \& Ehrig, H.-J. (1982), Enhancement of gas production in sanitary landfill sites. Resource Recovery from Solid Wastes. Proceeding of a Conference held in Miami Beach, Florida, U.S.A., May 10-12, Pergamon Press.

Walsh, J. (1983), Laboratory landfill gas enhancement and technologies in lysimeters. SCS. Engineers, Los Angeles, U.S.A. Sixth Annual International Landfill Gas Symposium, March 14-18, Industry, California GRCDA.

Wehran, F. (1983), Increased landfill gas generation through leachate recycling, wehran engineering. Sixth Annual International Landfill Gas Symposium, March 14-18, Industry, California GRCDA. 